\title{
Dendrogeomorphology in badlands: Methods, case studies and prospects
}

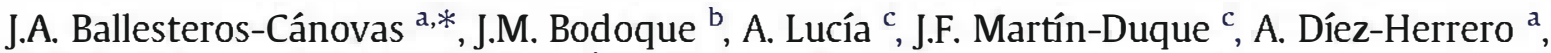 \\ V. Ruiz-Villanueva ${ }^{a}$, J.M. Rubiales ${ }^{\text {d, M. Genova }}{ }^{\mathrm{e}}$ \\ a Department of Research and Geoscientific Prospective, Geological Survey of Spain (IGME), Rios Rosas 23, Madrid E-28003, Spain \\ b Mining and Geological Engineering Department, University of Castilla La Mancha, Campus Fábrica de Arnas, Avda. Carlos III, Toledo E-5071, Spain

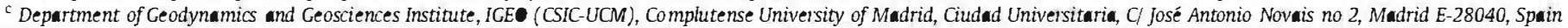 \\ a Departamento de Silvopascicultura, Escuela de Ingenieria Forestal y del Medio Natural, Universidad Politécnic de Madrid, Ciudad Universitaria s/n. 28040, Madrid, Spain \\ ' Department of Plant Production: Botany and Piant Protection, Technical University of Madrid, Ciudad Universitaria s/n. 28040, Madrid, Spain
}

\section{Keywords:}

Tree-ring

Dendrogeomorphology

Badlands

Gully erosion

Sheet erosion

\begin{abstract}
A B S T R A C T
Soil and vegetation are interacting factors controlling erosion. Soil degradation processes may affect the normal tree and shrub development and inversely, vegetation can modulate the velocity and intensity of soil development or denudation. A dendrogeomorphological approach can be used to study these interactions, allowing to obtain a date and estimate mean or specific erosion rates. This is especially useful in an unrecorded badlands and gullied environments, where the scarce vegetation may be the only proxy available to quantify the different geomorphic processes which have occurred. This paper provides a fundamental review of the dendrogeomorphological methodology applied to erosion measurement in badlands. Focusing on the response of the vegetation to the geomorphic processes, this paper: (a) describes the methodology developed to estimate erosion rates with exposed roots; (b) shows new advances through case studies; and finally, (c) discusses future lines of research to reduce methodological uncertainties and for making dendrogeomorphology more widely applicable.
\end{abstract}

\section{Introduction}

Badlands are usually defined as extremely dissected landscapes with short steep slopes and narrow interfluves that can support sparse vegetation but are anyhow unsuitable for agriculture (Bryan and Yair, 1982). Closely related to the badlands are the gullies, described as linear erosive forms that may initiate or reactivate badland development (Gallart et al., 2002). In short, badlands are barren landscapes intricately dissected by rills and gullies (Campbell, 1997).

Badlands and gullies are among the most significant areas of erosion in the world (Nadal-Romero et al., 2011; Poesen et al., 2003). The substratum of these landforms is usually characterized by unconsolidated or poorly cemented materials. Most of them occur in fine material (e.g., marls, shales, silts and clays) although they may also occur in poorly consolidated sands (Bryan and Yair, 1982). They develop predominantly in horizontally bedded, relatively impermeable rocks (Campbell, 1997). The climates where badlands and gullies occur occupy a wide range of conditions, although they are commonly found in semiarid areas with strongly marked seasonal contrast and, to a lesser extent, in sub-humid and humid regions and also

\footnotetext{
* Corresponding author.

E-mail address: ja.ballesteros@igme.es (J.A. Ballesteros-Cánovas).
}

desert zones (Bryan and Yair, 1982; Campbell, 1997; Nadal-Romero et al., 2011; Torri et al., 2000).

Many processes are involved in the origin and evolution of these landscapes including rain splash, overland flow, piping, mass wasting processes, fluvial and human activity (Campbell, 1997). The result of these is a wide-ranging variability of landforms. Different processes in badlands and gullies are also highly variable depending on the study area and on the spatial scale, so that extrapolating results is not considered appropriate (Bryan and Yair, 1982). Given the high variability of these processes, gullies and badlands have been studied using different approaches and techniques (Table 1):

a) Weathering processes have been studied in relation to soil temperature (Regüés et al., 2000), to regolith thickness (Marín and Desir, 2008) and regolith temperature and moisture (Regüés et al., 1995, 2000).

b) Creep and mudflows have been studied by using pins (Godfrey et al., 2008); volumes mobilized with mudflows have been quantified (Marin and Desir, 2008) and gully side mass movements, altogether with gullying, have been analyzed by comparing DEM produced with photogrammetry of before and after aerial photographs (Martínez-Casasnovas et al., 2009) and other topographic field surveys (Giménez et al., 2009).

c) Sheet erosion within badlands has been studied with erosion pins (Crouch, 1990; Della Seta et al., 2007; Godfrey et al., 2008; Sirvent et al., 1997); by measuring height variation in pedestals (Della 
Table 1

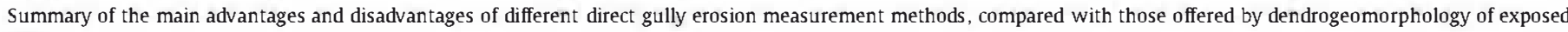
roots.

\begin{tabular}{|c|c|c|}
\hline $\begin{array}{l}\text { Method of direct measurement } \\
\text { of erosion in badlands }\end{array}$ & Advantages & Disadvantages \\
\hline Topographic microprofilers & Acceptable accuracy in estimation of soil lowering. & $\begin{array}{l}\text { High temporal resolution requires considerable time and effort. } \\
\text { Only valid for monitored sections. }\end{array}$ \\
\hline Erosion pins or bars & $\begin{array}{l}\text { Acceptable accuracy in estimation of soil lowering. } \\
\text { Adequate spatial cover possible. }\end{array}$ & $\begin{array}{l}\text { High temporal resolution requires considerable time and effort. } \\
\text { Pins and bars themselves interfere in the erosive process } \\
\text { producing uncertainty in measurements. }\end{array}$ \\
\hline Instrumented catchments & $\begin{array}{l}\text { Very good temporal resolution, sometimes even } \\
\text { continuous measurements available. }\end{array}$ & $\begin{array}{l}\text { No adequate control of spatial distribution of processes because } \\
\text { rates are only controlled at the outlet point, giving average } \\
\text { spatial rates. }\end{array}$ \\
\hline Experimental plots & $\begin{array}{l}\text { High temporal resolution, sometimes even } \\
\text { continuous measurements available. } \\
\text { Closed plots allow good comparisons of different } \\
\text { land uses or hydrological response units. }\end{array}$ & $\begin{array}{l}\text { Only representative of conditions of the monitored plot, difficult } \\
\text { spatial extrapolation. } \\
\text { High temporal resolution requires time and effort. } \\
\text { If plots are closed, life span of the plot is limited. }\end{array}$ \\
\hline $\begin{array}{l}\text { Microtopographic } \\
\text { multitemporal methods } \\
\text { (photogrammetry, LIDAR, } \\
\text { INSAR, Terrestrial Laser Scanner) }\end{array}$ & $\begin{array}{l}\text { Uniform spatial cover of the process in whole monitored area. } \\
\text { Acceptable accuracy in the estimation of soil lowering. }\end{array}$ & $\begin{array}{l}\text { High temporal resolution requires great time and cost. } \\
\text { Allow estimation only of average rates, not those corresponding } \\
\text { to singular events. }\end{array}$ \\
\hline Radioisotopic methods $\left({ }^{137} \mathrm{Cs}\right)$ & $\begin{array}{l}\text { Uniform spatial cover. } \\
\text { Acceptable accuracy in estimation of soil lowering. }\end{array}$ & $\begin{array}{l}\text { Measurement problems during specific moments in the process. } \\
\text { Expensive method requiring lab work and complex devices. }\end{array}$ \\
\hline Dendrogeomorphology & $\begin{array}{l}\text { High accuracy in estimation of soil lowering or deposit. } \\
\text { Estimation of average rates and also from singular events. } \\
\text { Can provide medium term erosion rates since the } \\
\text { year roots were exposed. }\end{array}$ & $\begin{array}{l}\text { Year or seasonal temporal accuracy (early or late wood) or } \\
\text { non-homogeneous spatial distribution of sampling points. }\end{array}$ \\
\hline
\end{tabular}

Seta et al., 2007), and with runoff and sediment collectors in closed microplots used for both natural rain and simulated rainfall experiments (Mathys et al., 2005).

d) Rills in gullies and badlands have been documented as more permanent than those developed in labs or in other environments such as agricultural land; rill erosion has been measured by characterizing drainage patterns and rill morphology (Kasanin-Grubin and Bryan, 2004) or by collecting runoff and sediment directly from the rill catchment with devices such as Geib-type divides (Sirvent et al., 1997) or pit totalizer samplers (Godfrey et al., 2008).

e) Sediment yield at catchment scale has been studied monitoring different parameters such as water discharge, suspended sediment concentration, dissolved soil concentration and bedload rates. These monitored catchments are usually small (from 0.1 ha to $100 \mathrm{ha}$ ) (Chocrom et al., 2007; Latrón and Gallart, 1995; Nadal-Romero et al., 2008a,b; Regüés et al., 2000; Soler et al., 2008).

In this sense, the application of dendrochronology to geomorphology has allowed the dating and study of processes from a different perspective. Dendrogeomorphology (Alestalo, 1971) offers a great versatility as a method to characterize erosive processes in badlands, either to be used to study ungauged watersheds, to calibrate empirical methods, or as a tool to complement other methods of direct estimation. So, dendrogeomorphology enables to obtain erosion rates over large areas, provided that there are exposed roots of tree species with good dendrogeomorphological aptitude (Grissino-Mayer, 1993) and they are located in homogenous units in terms of their response to erosion (Bodoque et al., 2011). Other methods of direct estimation (e.g., erosion plots) allow to obtain more accurate data regarding soil erosion at event scale. However, it is not feasible from an economic standpoint and human resources availability to install such devices in all basins that make up a badland site. Although erosion rates obtained from dendrogeomorphology define average values in units of $\mathrm{mm} \mathrm{yr}^{-1}$, however, this method can provide information regarding the characteristics of the erosive process. Specifically, the seasonal period in which exposure occurs can be determined. As a consequence, it may be established if erosion soil existing in a given site is a result of the occurrence of few precipitation events, instead of being a representative mean value of the whole year. In the early studies, conducted by La Marche (1963, 1968) and Eardley and Viavant (1967), the methodology for estimating soil denudation using exposed roots was developed. These were followed by the work by Carrara and Carroll (1979), Hupp and Carey (1990) and Danzer (1996) and the methodology was extended to studying: sheet erosion in different environments (Malik, 2008; McAuliffe et al., 2006; Pérez-Rodríguez et al., 2007); human impact on mountain hiking trails (Bodoque et al., 2005; Pelfini, 1999); erosion on lake shores (Fantucci, 2006); or along river banks (Begin et al., 1991; Hitz et al., 2008; Malik and Matyja, 2008; Stoffel et al., 2012); debris flow tracks (Gärtner, 2003, Gärtner et al., 2001); and even to determine fluctuations in caribou herds in Canada (Boudreau et al., 2003). Furthermore, the analysis of adventitious roots has been also used for dating sedimentation events resulting from different geomorphic processes, such as debris flow (Friedman et al., 2005; Kent et al., 2001; Strunk, 1997) as well as for drift-sand dynamics in dunes (den Ouden et al., 2007).

This paper aims to show the usefulness of tree ring records for studying gully erosion in badlands environment. It provides a methodological understanding, shows the research opportunities and discusses future research topics aimed at reducing the uncertainties deriving from the method.

\section{Vegetation and erosion: responses and interactions}

There is broad consensus that vegetation plays an important role in the erosive process (Gallart et al., 2002; Osterkamp et al., 2011). Vegetation increased roots shear stress, which favors greater soil consistency (Nilaweera and Nutalaya, 1999) and allows more organic matter to be retained, encouraging soil particle cohesion by releasing glue-like root exudates (Degens et al., 1994) which improve aggregated soil stability (Burri et al., 2009; Gros et al., 2004). In addition, forest cover intercepts rainfall and reduces raindrop impact energy, therefore decreasing the rain splash effect (Park et al,, 1983). The result is that soils are better protected against rainfall impact and the infiltration capacity is increased, reducing the surface runoff magnitude and the erosion capacity (De Baets and Poesen, 2010). In fact, vegetation and land use cover is considered as a main parameter in the most important physical erosion models (Wang et al., 2004) and its variation over time has been taken into account in erosion dynamics studies (McAuliffe et al., 2006). 
However, the interaction between vegetation and the erosive process is bidirectional, and it has been shown to control the biodiversity and development of vegetation (Gallart et al., 1993; Osterkamp et al., 2011; Rey et al., 2005). From a global perspective, the erosive process directly affects seed germination, and consequently the positioning of plants due to removal of the organic soil horizon (Butler et al., 1986; Guàrdia et al., 2000). The erosive process in badlands areas is considered to be regressive, which means a gradual disappearance of original species and a decrease in biodiversity (Guerrero-Campo, 1998). In turn, a decrease in vegetation cover causes a reduction in soil formation and promotes further erosion (Thornes, 1985).

From a general viewpoint, the rapid loss of species and low substitution rates are thought to involve a high degree of homogeneity among plant communities, only differentiated by the presence or absence of the most sensitive species to erosion (Guerrero-Campo,
1998). However, species and coverage distribution patterns have also been used to demonstrate that other factors (e.g., climatic conditions) are also crucial for the occurrence of badlands (Regüés et al., 2000).

From a local perspective, erosion also affects the development of individual trees and shrubs (Chartier et al., 2009; La Marche, 1963). The different effects that can be recognized on trees within gullied areas, include: i) root exposure by denudation; ii) root displacement by sudden erosion events; and iii) partially buried trees, which can be used to determine the process magnitude. This offers an opportunity to study this process through tree-ring records. Following the dendrogeomorphic concept of 'process-event-response' established by Shroder (1980), a geomorphic process like soil erosion may interfere with vegetation generating an external disturbance on trees. This damage is linked to a determinate event and provokes a response

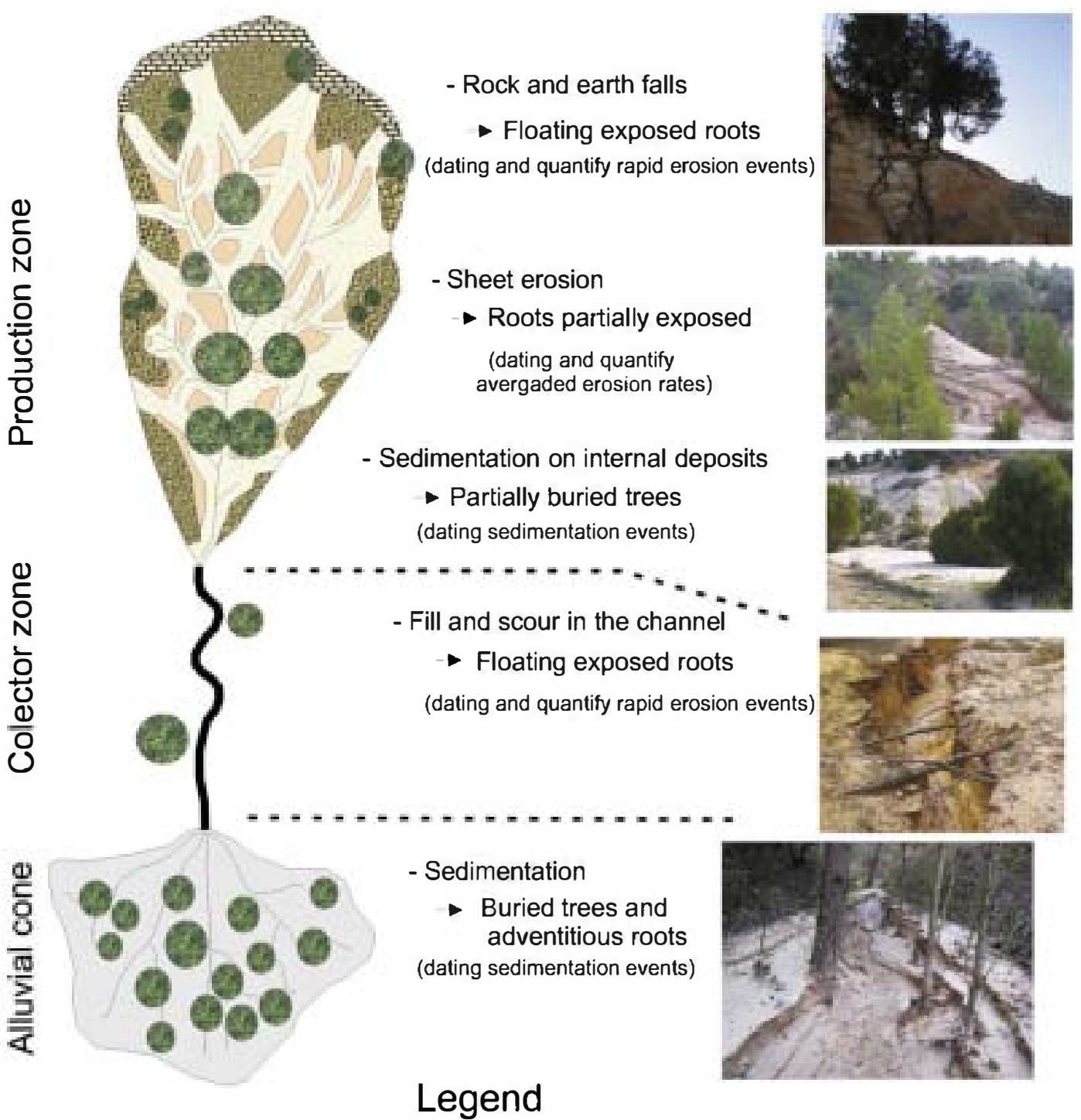

Tree vegetation

Exposed sand with moderate slopes

Surficial deposits

Caprock

Divides

Exposed sand with steep slopes

Flow lines

Fig. 1. Dendrogeomorphological evidence can be found in each different zones of an idealized partially vegetated gully. 
in the tree growth development, which offers a real possibility of studying the erosion in badlands through tree-rings and vegetation dynamics analysis (Chiarucci et al., 1995).

In an idealized, partially vegetated, gullied catchment, root exposure can be found in those areas within the catchment where sheet erosion is predominant, generally in the production zone (Fig. 1). In these cases, the eroded soil can be measured from the highest point of the root cross-section to the current soil level. Assuming the rates are continuous, they can be determined using the root exposure time. Determining the first year of exposure is therefore essential to estimate average erosion rates over a specific time period. Eccentric ring growth is one of the most common visible growth changes after root exposure (Fig. 2A); although sometimes abrasion scars of cambium tissues can also be detected, easily dated by locating the callus tissues in the tree-ring record (Ballesteros et al., 2010a,b; Schneuwly et al., 2009). However, anatomical analysis has shown to be essential, precisely because of the difficulty in differentiating the growth rings in roots (Fayle, 1968; Gärtner et al., 2001). The main anatomical changes observed in conifer trees are related to the increasing growth ring thickness due to a greater number of cells in earlywood (EW) (Fig. 2B). A reduction has also been observed in the lumen area of EW tracheids and an increased cell wall thickness of latewood (LW) tracheids (Bodoque et al., 2005; Carrara and Carroll, 1979). These changes have been linked to the response of coniferous trees to environmental stress due to changes in the atmosphere and light conditions of the roots, with consequences at a physiological level (Antonova and Stasova, 1993, 1997). However, as root denudation does not occur immediately, the anatomical structure undergoes a gradual change, described by Rubiales et al. (2008) and more recently quantified by Corona et al. (2011).

Root displacement (Fig. 1) can be found associated with landslides in basin headwaters, in areas of abrupt slope change, and in the transfer channel. This exposure is generally provoked abruptly due to a local ground fault by specific erosion events. The erosion value determined with this type of root sample corresponds to a specific event and may provide information about the event magnitude (Vandekerckhove et al., 2001). In this case, the growth response may be generalized to tree-rings in the stem, especially when roots are floating completely or there are visible dead end hanging roots. This is because the water storage capacity may be reduced as well as the nutrient supply and this may also affect the growth hormone generation center with a direct effect on tree growth (Aloni et al., 2006). At an anatomical level, the changes in softwood are similar to root exposure by denudation, but they are more intense. Root exposure by rapid events in deciduous species has been also studied (Hitz et al., 2008). In European ash, the major anatomical change was related to a reduction in EW vessels and fibre cells.
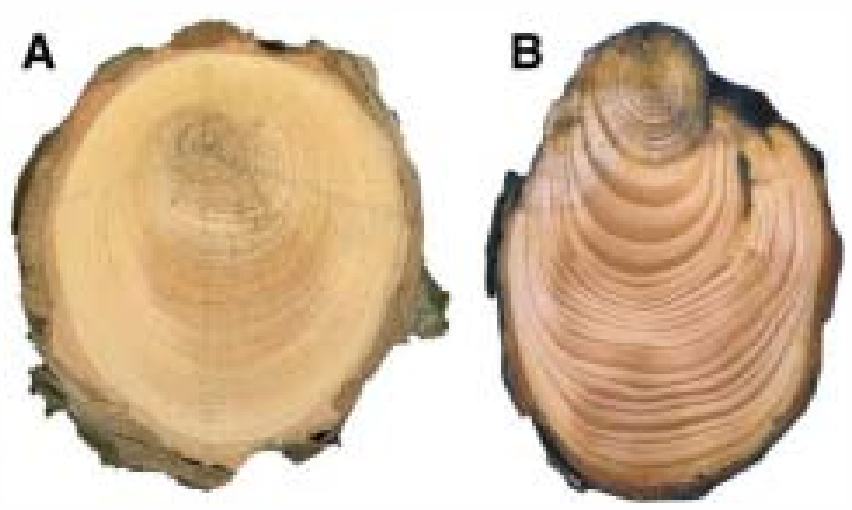

Fig. 2. View of a polished section of a root exposed without scars (A) and with scar (B). In both cases, it is possible to see the pattern of eccentric growth rings in response to erosion processes
Finally, the material transported by the channel is deposited downstream in the alluvial cone. In this area, partially buried trees may be found, although this type of evidence can also be observed in smaller local depositional areas within the production zone (Fig. 1). The tree growth response is generally characterized by a decrease in ring width, because trees may have greater difficulty in supplying water and nutrients (Malik and Owczarek, 2009). Sometimes, however, when deposition material is rich in nutrients, trees may respond with greater growth (Strunk, 1997). In these trees, meristematic cells located in the cambium tissue of the buried section of the trunk can differentiate and produce adventitious roots in the year after burial (Strunk, 1997). This type of evidence has been used for studying sediment in different geomorphic processes (Bollschweiler, 2007; Strunk, 1997) and also in aeolian environmental studies (den Ouden et al., 2007).

\section{Dendrogeomorphological methods for soil erosion assessment}

The application of dendrogeomorphological methods to study erosive processes requires a multidisciplinary approach, including ecological, geomorphologic and topographic techniques, which may in turn be linked with traditional erosion measurement procedures as well as with hydrological and hydraulic step procedures. Fig. 3 shows the different work required to estimate erosion rate.

\subsection{Sampling strategy}

Before starting the tree root analysis and sampling procedure, the processes involved and differing badland behavior need to be determined using classical geomorphologic methods. These include field observations and a detailed geomorphic mapping of the area usually accomplished in dendrogeomorphological studies (e.g., Gärtner, 2007; Stoffel et al., 2010). The production zone, the collector or wansfer zone and the deposition zone with species suitable for tree-ring analysis (in which the annual formation of growth rings has been demonstrated) must be identified (Grissino-Mayer, 1993). This is because the treering records of roots in each zone can provide information about the process on different time scales. The land features may also be very different in the three zones (i.e., geological substratum, texture and structure of soils, slopes). Slopes are generally higher in the drainage area and much lower in the deposition zone. The most approporiate procedure is to define and map Hydrologic Response Units (HRU) within the studied area, including homogeneous geological substratum, soil, surface deposits, canopy cover and vegetative residue surface cover, and establishing a range of slope gradients (Bodoque et al., 2011). The interrelationships between bedrock, topography, soil and vegetation reflect a common hydrological and erosive response within each HRU (Lucía et al., in press). This can be done with aerial photos and field surveys with topographic devices (GPS, Total Station), taling soil samples to ensure a homogeneous hydrological response in terms of textural characteristics, organic matter content, permeability and cohesiveness (Bodoque et al., 2011). To interpret the erosion rate data obtained, a time-based analysis from historic aerial photos or from historic data is also useful (Vicente et al., 2009).

Other considerations should then be taken into account before sampling the observed exposure roots. To avoid any misrepresentation in the targeted reconstruction, root samples from trees should be taken at a minimum distance from the stem base. This is because the stem base migrates upwards due to ongoing growth (Gärtner, 2007; La Marche, 1968) and roots close to the stem base may show an anomalous growth pattern due to mechanical stresses exerted by the stem (Gärtner, 2007). Although the area of influence of structural roots can be approached from the diameter measured at breast height (DBH, Koizumi et al., 2007), normally authors use a simplified value ranging from 0.5 to $1.5 \mathrm{~m}$ (Bodoque et al., 2011; Corona et al., 2011; Gärtner, 2007). Another sampling limitation derives from the local 


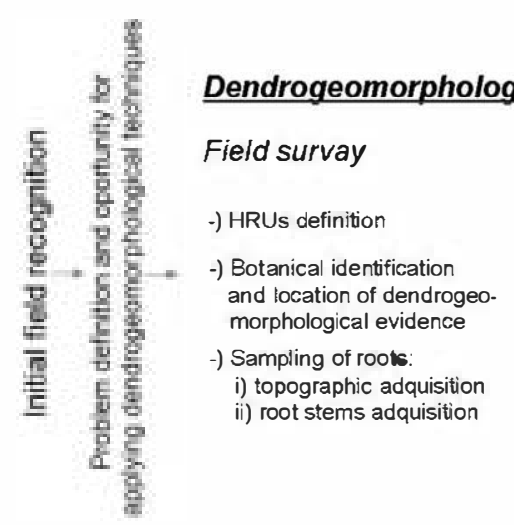

Laboratory procedures
-) Definition of soil properties
-) Mapping sampling areas
-) Current eroded soil
-) Wood anatomic analysis
(first year of exposure)

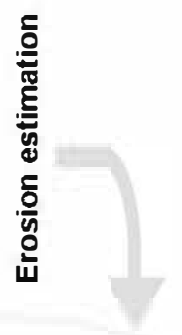

\author{
Linking with other methods \\ -) Direct methods \\ (results verification with systematic records) \\ -) Hydrological models \\ (results as initial conditions)
}

Fig. 3. Flow diagram of the tasks necessary to carry out tree-ring studies of gully erosion.

aspect of exposure roots. Sampled roots must be orientated along the direction of the maximum hillside slope. This is because in other cases, the root tends to act as a small dam, retaining sediments on one side and remaining bare on the other, and therefore distorting the soil erosion measurements (Bodoque et al., 2005).

The position of the exposed roots with respect to the present soil surface must be documented in detail. For sheet erosion rate estimation, a depth gauge is normally used to measure the distance between the upper part of the root and the current soil surface, although newer accurate devices could be also used (i.e., Terrestrial Laser Scanner, TLS). However, to estimate erosion by root displacement from a specific event the mobilized volume must be determined. To do this, the orthogonal position and depth measurement have to be obtained to estimate the amount of eroded soil (Vandekerckhove et al., 2001). Other basic information is always provided, such as the accurate geographical location; altitude; aspect, both for the hillside and for the specific root location; hillside slope and slope of the specific root location. Most of these parameters are included in the HRU mentioned above. Generally, sections of the exposed roots are cut with a handsaw (Fig. 4), but cores could also be extracted from the thicker exposed root area (see method in Gärtner, 2007).

\subsection{Laboratory procedure}

After the field survey, samples must be left to dry in the open air as required (1-2 months). Then, two disks with an approximate thickness of $1.5 \mathrm{~cm}$ are obtained from the initial section and sanded and polished with sandpaper (up to 400 grit) to facilitate recognition of the tree-rings (Gärtner et al., 2001).

One of the sections is used for dendrochronological dating and macroscopic assessment of the yearly growth pattern. To do this, several radii should be marked along the direction that shows the highest variability in width measurements of the growth rings. Growth rings should be accurately measured, usually with a measuring device coupled to a stereomicroscope. The date of each tree-ring can be determined by visual and statistical cross-dating techniques (Fritts, 1976; Schweingruber, 1996). Visual analysis of overlapping graphs can be used to determine the presence of discontinuous, multiple rings and dating of the series. However, there are specific software available for crossdating, as TSAPWin (Rinntech, 2008), COFECHA (Holmes, 1983), or CDendro (Larsson, 2003). An extensive collection of software and methods can be found at Grissino-Mayer (2011; http://web.utk.edu/ grissino/).
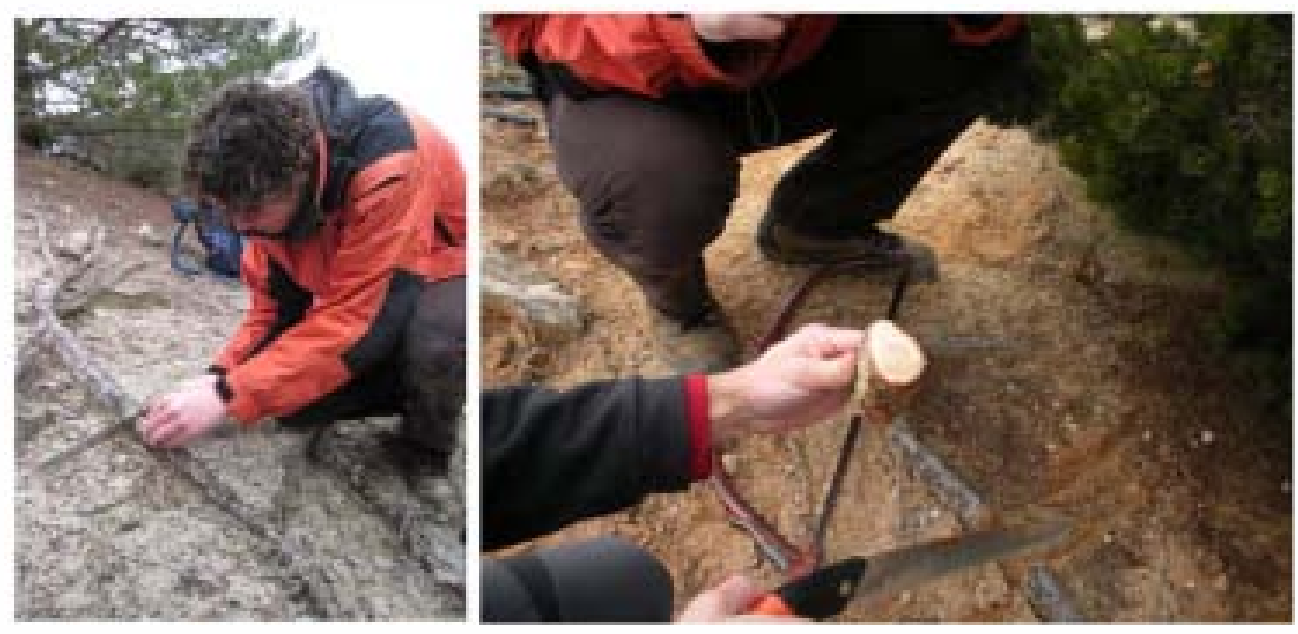

Fig. 4. Sampling exposed root by sheet erosion oriented according to the slope direction with a hand saw. 
The other section is used for determining the first year of response to soil erosion by anatomical criteria. To do this, samples should be re-sized and softened by soaking them in different mixtures of water and alcohol to facilitate the sectioning procedure when there is abundant resin in the xylem of the samples. Sections of approximately $1 \mathrm{~cm}$ wide and $20 \mu \mathrm{m}$ thick should be obtained along the radial plane with a sliding microtome. After that, staining with safranin should be carried out as described by Schweingruber (1993). Finally, sections have to be embedded in a hardening epoxy (e.g., Eukitt or canada balsam) and dried. After this procedure, the samples have to be observed under optical microscopy and photographed with a digital imaging system to analyze the microscopic images. 50 $\times$ magnification is normally used for this, with specific software such as WinCell PRO which allows automatic measurement of different anatomical parameters with $1 \mu \mathrm{m}$ precision. The anatomical parameters generally analyzed as good indicators of the occurrence of first year exposure according to the literature in conifers (Rubiales et al., 2008), are: a) increase of ring width; b) increased percentage of latewood; c) significant decrease of cell lumen area of early tracheids (Fig. 5). All these parameters can be compared using different statistical tests (Ballesteros et al., 2010a,b). Although no common pattern of response to exposure has been detected in hardwoods, the anatomy of some species (i.e., Fraxinus) shows changes in vessel and fibre dimensions (Hitz et al., 2008) after exposure.

\subsection{Erosion rate estimation}

With the date of the first year of root exposure (based on analysis of root-ring growth and anatomical changes) and the measurement of the eroded soil layer, erosion rates can be reconstructed. All empirical equations used for erosion rate estimation are related to the difference in amount of eroded soil divided by the time defined by the root exposure (Bodoque et al., 2005, 2011; Corona et al., 2011; Gärtner, 2007; Lopez- Saez et al., 2011; Vandekerckhove et al., 2001).

The simplified erosion rate equation is:

$\mathrm{ER}=\frac{\Delta \mathrm{E}_{\mathrm{S}}}{\Delta \mathrm{Y}_{\mathrm{ER}}}$

where $\Delta E_{\mathrm{s}}$ is the difference in the amount of eroded soil and $\Delta Y_{E R}$ is the number of years the root has been exposed. When estimating the erosion of a specific event by root displacement, $\Delta E_{\mathrm{s}}$ corresponds to the volume difference estimated in situ (ER expressed as $\mathrm{m}^{3} \mathrm{yr}^{-1}$ ), whereas in the case of sheet erosion, $\Delta E_{\mathrm{s}}$ corresponds to the eroded soil depth (ER given in $\mathrm{mm} \mathrm{yr}^{-1}$ ). However, for sheet erosion, the following effects also have to be taken into account: i) the relative root uplift caused by the consecutive secondary root growth after exposure, especially in consolidated soils (Gärtner, 2007); and ii) the anatomical response to erosion when there is still a thin layer of soil, quantified as $30 \mathrm{~mm}$ for limestone soils (Corona et al., 2011). Fig. 6 shows possible cases for estimating $\Delta E_{\mathrm{s}}$ in exposed roots by sheet erosion. In a simple form, the depth of eroded soil that can be quantified with anatomical criteria $\left(\Delta E_{\mathrm{s}}\right)$ is positively related to: $\left.i\right)$ the difference between the soil level and the upper point of the root $\left(\Delta E_{\text {soil }}\right)$ when they are sampled $(t=0)$; ii) soil depth at which the root responds anatomically $\left(\varepsilon, t=-2\right.$ ). Additionally, $\Delta E_{\mathrm{s}}$ is negatively related to the secondary growth of the root from the first year of exposure until

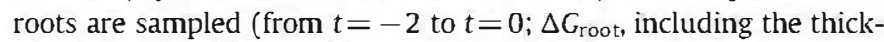
ness of bark). This equation can be simplified according to:

$\Delta E_{\mathrm{s}}=\Delta E_{\text {soil }}+\varepsilon-\Delta G_{\text {root }}$

further details about this equations can be found in Gärtner (2007) and Corona et al. (2011).

\section{Dendrogeomorphology for soil erosion assessment in badlands: history and new advances}

Despite its potential usefulness, this technique has hardly been applied to gullies and badlands studies. The first study on gullies was conducted by Vandekerckhove et al. (2001) and describes in detail the different cases of exposed roots which can be found in a gully to determine eroded volumes. As a case study, these authors presented successful erosion rate estimates in a non-recorded gullied area in SE Spain using different Mediterranean species. The main limitations described by these authors include simple assumptions about the erosive process and root growth due to the difficulty of estimating the eroded volume accurately and the problems of cross-dating some species to assign a correct age to each tree-ring. However, despite these problems, their results allowed them to report estimations of the headwall gully retreat rate and the average minimum sidewall erosion rate per unit measuring an average of $6 \mathrm{~m}^{3} \mathrm{yr}^{-1}$, finding that they are not significantly different from field measurements in the same areas $4 \mathrm{~m}^{3} \mathrm{yr}^{-1}$, (Vandekerckhove et al., 2001; average basin area $8.5 \times 10^{4} \mathrm{~m}^{2}$ ). However, they noticed that medium term measurements (dendrogeormorphology and aerial photos) tend to measure higher rates than short term methods, because it measured the average of both small and extreme events. They also found a high correlation between gully retreat rate and drainage-basin area which indicated the important contribution to the erosive process of the drainage basin. Both conclusions were important to understand the link between catchment characteristics and the magnitude of
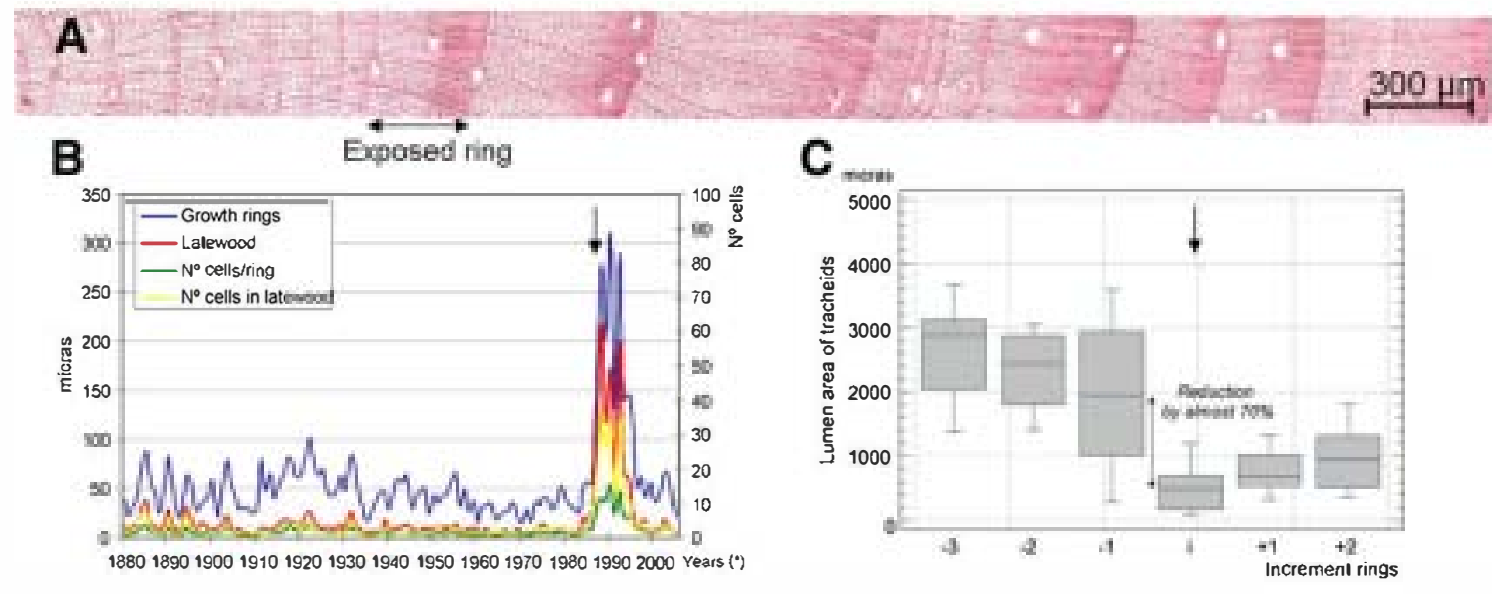

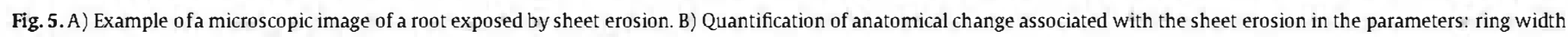
and latewood amount; as well as in the lumen of earlywood cells (C). 


\section{Exposed root}

$t=-3$

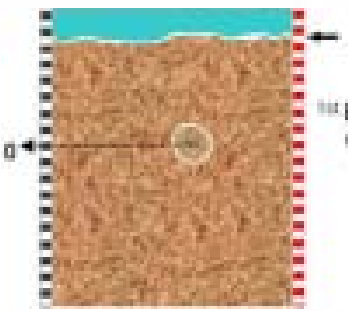

$t=-2$

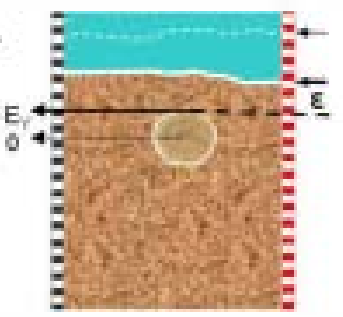

$t=-1$

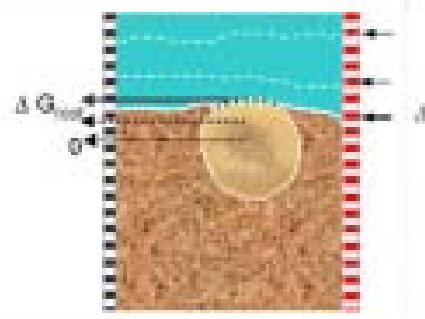

Current $(t=0)$

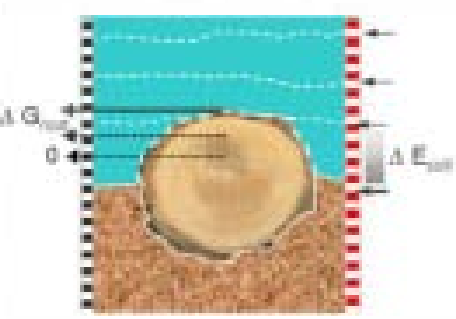

\section{Exposed root with scar}
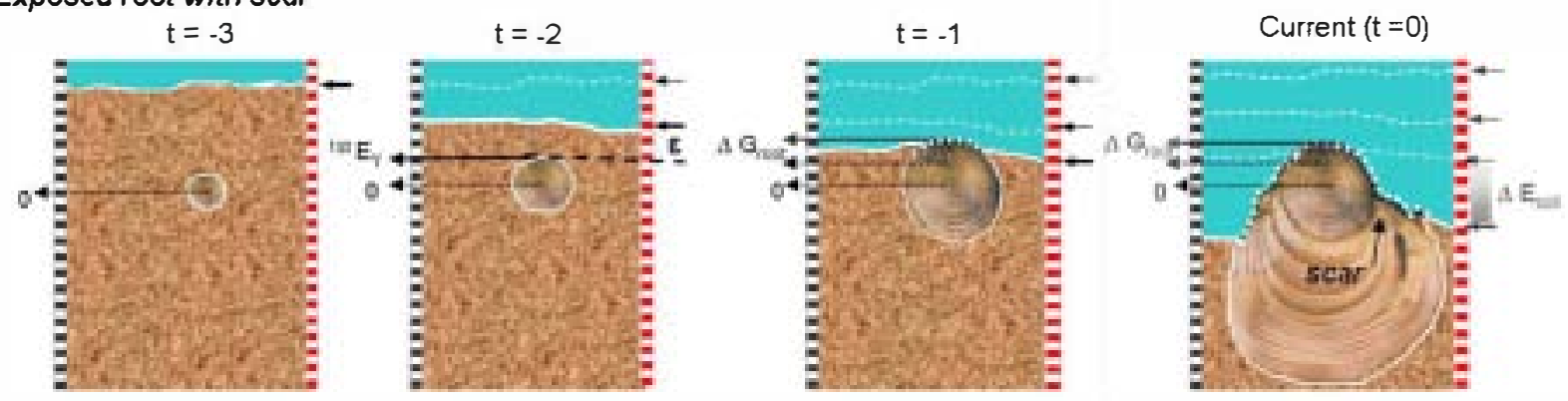

u u u a. Root growth

॥... Depth soil

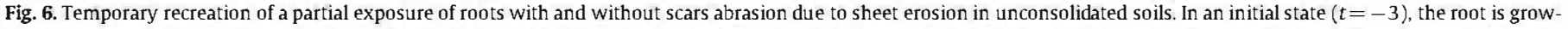

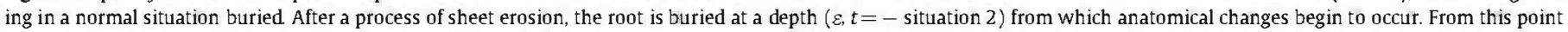

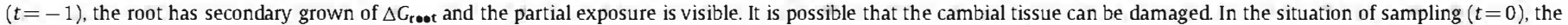

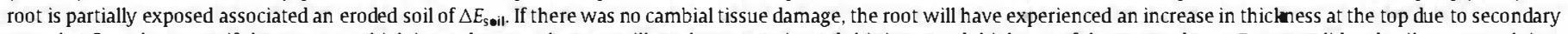

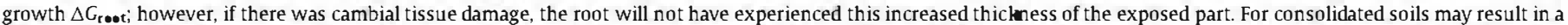

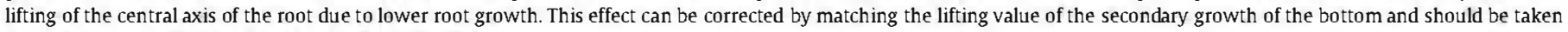
into account to estimate soil erosion in these situations.

erosion in southern Spain and represent a major advance in the application of dendrogeomorphological techniques to badlands. Malik (2008) studied gully erosion by mean of floating exposed roots in different points of small gullies in shouthern Poland, he obtained a gully retreat of $0.63 \mathrm{~m} \mathrm{yr}^{-1}$.

Three studies have recently appeared which represent advances in both practical application to unrecorded areas and in methodology. Bodoque et al. (2011) applied tree-ring analysis to exposed roots to determine the sheet erosion rate in a set of slope gullies on the northern piedmont of the Guadarrama Mountains (Spanish Central System). The most significant contribution was to take into account the hydrological response units (HRUs) approach during the sampling stage, so that the erosion rates estimated can be extended to similar gullied areas. In this work it was used anatomical criteria to locate the first year of exposure as well as dendrochronological techniques to properly allocate the year to each ring. In this regard, the uncertainties associated with false or double rings, which appear with high frequency in roots, were minimized using cross-dating techinques. In this same area, erosion pins were surveyed during three hydrological years. During this period an extreme event estimated on 175 years return period occurred. The average sheet erosion rate obtained from erosion pins was $11.9 \mathrm{~mm} \mathrm{yr}^{-1}$ (Lucía et al., in press), higher than the average erosion rate estimated with dendrogeomorphology $(6.2-8.8 \mathrm{~mm} / \mathrm{yr}$, Bodoque et al., 2011). The difference may be due to the fact that the weight of these extreme events are smoothed in longer term estimates, as it happens with dendrogeomorphology, from where average erosion rates are derived. Moreover, the time series used in the dendrogeomorphic assessment was longer than the one recorded from erosion pins. Additionally, it was observed a discrepancy in the response of different anatomical parameters of earlywood and latewood, related to the season in which sheet erosion is higher, due to the occurrence of storms.

Two additional studies have been carried out in France (Corona et al., 2011; Lopez- Saez et al., 2011). The first is a methodological advance in estimating the soil denuded by sheet erosion in badlands. The second is the first attempt to map soil erosion rates from the combined use of dendrogeomorphologic analysis of exposure roots and high accuracy topographic data derived from LiDAR. To estimate the eroded soil, Corona et al. (2011) established two different hypotheses related to the possibility that root growth after exposure may or may not be affected by the ground. They considered the approach established by Gärtner (2007) to estimate the effect of the secondary xylem root growth and demonstrated that anatomical changes due to continuous soil denudation occur $30 \mathrm{~mm}$ before the root is exposed. The results they obtained (5.9-6.2 $\mathrm{mm} / \mathrm{yr}$ ) matches with data obtained from denudation measurements performed with marking during nine years. Lopez- Saez et al. (2011) used estimated erosion rates obtained from dendrogeomorphology to produce a linear regression model using slope as an independent variable. This model predicted almost half of the erosion variability and was used to generate a high resolution erosion map for the whole catchment. Their results also agree with the sediment yield measured at the outlet of the catchment.

\section{Research needs}

Research aimed at estimating erosion rates by dendrogeomorphologic techniques has so far focused primarily on determining the first year of exposure. To achieve this, many attempts have been made to study the anatomical changes that occur in wood in response to exposure. To a 
lesser extent, work has also been carried out on developing equations that take into account the relative root rise in relation to its axis due to secondary xylem growth (Corona et al, 2011; Gärmer, 2007). One of the parameters used in these equations is the eroded soil measurement, obtained by measuring the exposed root height with a tape measure or hand gauge on both sides of the root (Bodoque et al., 2005). However, as noted by Vandekerckhove et al. (2001) this methodological approach has generated considerable uncertainties in the rates measured for two reasons. First, the height of eroded soil has been measured at points of contact between soil and root. However, sheet erosion does not generate a uniform eroded layer. On the contrary, it generates a surface whose microtopography must be known with pinpoint accuracy to obtain the variability in the height of eroded soil parameter. However, large exposed roots appear to protect the soil from erosion (Bodoque et al, 2011; Haubrock et al., 2009), so that the height of bare soil would be lower at the point of contact between the soil and roots than in their immediate environment. As a result, the rates estimated from these roots may be underestimated, as has been interpreted from the negative trend observed between the average erosion rate and the thickness of the root (Bodoque et al., 2011). In the same way, this may happen when trying to estimate the volume eroded during headcut retreat, because it is not certain that it takes place over the entire depth (Vandekerckhove et al., 2001).

To reduce the uncertainty level for eroded soil during sheet erosion estimation and to clarify in relative terms the variability of the soil microtopography, a detailed topographic data acquisition survey should be carried out. In this sense, TIS techniques could be used to verify the degree of validity of the rates measured with the conventional method and to study the differences in height between the root-soil contact and the other surface. Other methods such as three-dimensional scanning of replicas made in situ could be also performed. The replicas obtained in the first attempts to use this technique on exposed roots by sheet erosion, are being made in duplicate dental plaster prior to the dental plaster casting exaduro mixed with water. This material has a very low thermal expansivity and allows replica with highly accurate (E. Baeza and M. Hernández, pers. comm.). The process is completed with 3D scans of the replica using reverse engineering techniques, obtaining $x, y, z$ point clouds with high accuracy.

The highly accurate Digital Elevation Model (DEM) derived from the data aforesaid allows to carry out the analysis of the measures of the heights of eroded soil on various root cross-sections and longitudinal to the direction of advance of erosion. It also allows distance to be obtained from the root axis to the extent of soil erosion, and therefore to prevent the protective effect of the root on soil denudation. TLS is especially useful since it enables a very high precision data acquisition over a wide setting. In addition, this topography technology could also be used to estimate rock and earth fall in the upper part of the gully as well as fill and scour in the collector channels, because the measurement (in the order of $\sim \mathrm{m}^{3}$ ) can offer accuracy of more than a millimeter. This approach is, in fact, being successfully used by different researchers to monitor spatialtemporal gully dynamics (Lucia et al., in press).

Another point that requires further research is the tree species used to estimate erosion rates. Published studies have mainly used conifer roots for erosion estimations (Bodoque et al., 2005, 2011; Corona et al., 2011; Gärtner et al., 2001, Gärtner, 2003; Lopez- Saez et al., 2011). Here there is broad consensus on how the roots of these species respond clearly to exposure. In contrast, little or nothing is known about the behaviour of roots of hardwoods (such as oak or dycotiledoneous shrubs) that are widely represented in the Mediterranean geography. Because badlands and gullies are usually found in semi-arid climatic conditions, there is a lack of knowledge about how trees and shrubs growing in this climate respond to erosive processes. Due to unawareness about the formation and periodicity of growth rings in angiosperms, dendrochronological and anatomical wood studies of the trunk and root, should be increased and supplemented accurately in order to identify the first year of exposure.

Despite these uncertainties, one of the advantages of dendrogeomorphological analysis is that it reports precise estimation retrospectively. Nevertheless, it is a direct estimation method that requires significant invesment in human and economic resources and it is in some cases a difficult and time-consuming task, which means that work should be restricted to small study areas that are not always representative of their wider physiographical context. In this case, combining direct measurements of the erosive process with models can help to extend the process characterization to a wider geographical area. In the case of badlands, where erosive processes are considerable complex, the combination of dendrogeomorphology with data obtained from a gauged catchment where sediment yield is measured can help to conclude whether or not water erosion is the dominant erosive process. If so, the use of models such as SWAT (Jeong et al., 2010), after calibration and validation, may be used to estimate sediment emission from water erosion in the whole area where gullies develop, provided that sufficiently homogeneous weather patterns, soils and land use can be assumed. Indeed the use of tree-ring data with hydrometeorological models opens new possibilities of study that should be prospected.

\section{Conclusions}

The use of tree-ring research to estimate erosion rates in gullies and badland areas has some advantages over other techniques, but also opportunities for new implementations (see Table 1).

As has been widely investigated for years, gully erosion is usually not a linear and continuous process in time, but evolves via cycles of initiation, stabilization and accretion that occurs over decades, often episodically and at varying rates (see Whitford et al., 2010 and the reference within) related to specific events (heavy rainfall or sudden snowmelt) with a marked threshold effect. In this dynamics, other methods, such as terrestrial laser scanning every few years in the same area, only allow average rates to be obtained. Instrumented watersheds and experimental plots are able to collect these random temporary events; however this is also as an overall total measured at a mean collection point, not spatially distributed. Therefore, the study of exposed roots provides information on both average rates and on the dates and intensity of these events.

\section{Acknowledgments}

This study has been funded by the Research Projects CGL201021754-C02-01 and CGL2010-19274 (MAS Dendro-Avenidas) of the Spanish Ministry of Science and Technology and the project IDEAGESPPNN founded by the Environmental Ministry of Spain. We finally want to remember, affectionately, the memory of Andy Godfrey, who introduced us in the field of dendrogeomorphological analysis of exposed tree roots.

\section{References}

Alestalo, J., 1971. Dendrochronological interpretation of geomorphic processes. Fennia $105,1-140$.

Aloni, R, Aloni, E., Langhans, M., Ullrich, C.1, 2006. Role of cytolinin and auxin in shaping root architecture: regulating vascular differentiation, lateral root initiation, root apical dominance and root gravitropism. Annals of Botany 97, 883-893.

Antonova, G.F, Stasova, V.V, 1993. Effects of environmental factors on wood formation in Scots pine stems. Trees 7, 214-219.

Antonova, G.F., Stasova, V.V, 1997. Effects of environmental factors on wood formation in larch (Larix sibiric Ldb.) stems. Trees 11, 462-468.

Ballesteros, J.A., Stoffel, M, Bodoque, J.M, Bollschweiler, M, Hitz, O, Díez-Herrero, A., 2010a. Changes in wood anatomy in tree rings of Pinus pinuster Ait. following wounding by flash floods. Tree Ring Research 66 (2), 93-103.

Ballesteros, J.A., Stoffel, M, Bollschweiler, M, Bodoque, J.M., Díez-Herrero, A., 2010b. Flash-flood impacts cause changes in wood anatomy of Alnus glutinos, Fraxinus angustif oli and euercus pyrenaica. Tree Physiology 30 (6), 773-781. 
Begin, Y., Langlais, D., Cournoyer, L., 1991. A dendrogeomorphic estimate of shore erosion, upper ST-Iawrance estuary, Quebec. Journal of Coastal Research 7, 607-615.

Bodoque, J.M., Díez-Herrero, A, Martín-Duque, J.F., Rubiales, J.M., Godfrey, A, Pedraza J., Carrasco, R.M., Sanz, M.A., 2005. Sheet erosion rates determined by using dendrogeomorphological analysis of exposed tree roots: two examples from Central Spain. Catena 64, 81-102.

Bodoque, J.M., Lucía, A., Ballesteros, J.A., Martín-Duque, J.F., Rubiales, J.M., Genova, M., 2011. Measuring medium-term sheet erosion in gullies from trees: a case study using dendrogeomorphological analysis of exposed pine roots in central Iberia Geomorpholo gy 134, 417-425.

Bollschweiler, M., 2007. Spatial and temporal occurrence of past debris flows in the Valais Alps - results from tree-ring analysis, PhD. Thesis. Geo-Focus 20, $182 \mathrm{pp}$

Boudreau, S., Payette, S., Morneau, C., Couturier, S., 2003. Recent decline of the George River Caribou herd as revealed by tree-ring analysis. Arctic, Antarctic, and Alpine Research 35 (2), 187-195.

Badland Geomorphology and Piping. In: Bryan, R., Yair, A (Eds.), Geo Books, Norwich $408 \mathrm{pp}$

Burri, K., Graf, F., Böll, A., 2009. Revegetation measures improve soil aggregate stability: a case study of a landslide area in Central Switzerland. Forest Snow and Landscape Research 82 (1), 45-60

Butler, J., Goetz, H., Richardson, J.L., 1986. Vegetation and soil landscape relationships in the North-Dakota badlands. The American Midland Naturalist 116, 378-386

Campbell, LA, 1997. Badlands and Badland Gullies. In: Thomas, D.S.G. (Ed.), Arid Zone Geomorphology. Belhaven Press, London, pp. 159-183.

Carrara, P.E., Carroll, T.R., 1979. The determination of erosion rates from exposed tree roots in the Piceance Basin, Colorado. Earth Surface Processes 4, 307-317.

Chartier, M.P., Rostagno, C. M., Roig, F.A., 2009. Soil erosion rates in rangelands of north eastern Patagonia: a dendrogeomorphological analysis using exposed shrub roots. Geomorpholo gy 106, 344-351.

Chiarucci, A, De Dominicis, V., Ristori, J., Calzolari, C., 1995. Biancana badland vegetation in relation to morphology and soil in Orcia valley, central Italy. Phytocoenologia 6, 69-87.

Chocrom, M., Laronne, JB., Alexandrov, Y., 2007. Runoff and sediment supply form small gullied and ungullied basins in a semi-arid grazed environment. In: Casalí, J., Giménez, R. (Eds.), Progress in gully erosion research. Universidad Pública de Navarra, Pamplona, pp. 26-27.

Corona, C., Saez,J.L., Rovera, G., Stoffel, M., Astrade, L., Berger, F., 2011. High resolution, quantitative reconstruction of erosion rates based on anatomical changes in ex posed roots at Draix, Alpes de Haute-Provence - critical review of existing ap proaches and independent quality control of results. Geomorphology 125 433-444.

Crouch, R.J., 1990. Erosion processes and rates for gullies in granitic soils Bathurst, New South Wales, Australia. Earth Surface Processes and Landforms 15, 169-173.

Danzer, S.R., 1996. Rates of slope erosion determined from exposed roots of ponderosa pine at Rose Canyon Iake, Arizona. In: Dean, J., Meko, D.M., Sewtnam, T.W. (Eds.) Tree Rings, Environment, and Humanity. Radiocarbon 1996, Proceedings of the International Conference. University of Arizona, Tucson, pp. 671-678.

De Baets, Poesen, J., 2010. Empirical models for predicting the erosion-reducing effects of plant roots during concentrated flow erosion. Geomorpholo gy 118, 425-432

Degens, B.P., Sparling, G.P., Abbott, L.K., 1994. The contribution from hyphae, roots and organic-carbon constituents to the aggregation of a sandy loam under long-term clover-based and grass pastures. European Journal of Soil Science 45, 459-468.

Della Seta, M., Del Monte, M., Fredi, P., Lupia-Palmieri, E., 2007. Gully Erosion in Central Italy: Denudation Rate Estimation and Morphoevolution of Calanchi and Biancane Badlands. In: Casalí, J., Giménez, R. (Eds.), Progress in Gully Erosion Research. Universidad Pública de Navarra, Pamplona, pp. 36-37.

den Ouden, J., Sass-Klaassen, U.G.W., Copini, P., 2007. Dendrogeomorpholo gy - a new tool to study drift-sand dynamics. Netherlands Journal of Geosciences 86, 355-363.

Eardley, A.J., Viavant, W., 1967. Rates of denudation as measured by Bristlecone Pines Special Studies, voL 21. Utah Geological and Mineralogical Survey, Cedar Breaks, Utah.

Fantucci, R., 2006. Dendrogeomorphological analysis of shore erosion along Bolsena Lake (Central Italy). Dendrochronologia 24, 69-78.

Fayle, D.F.C. 1968. Radial Growth in Tree Roots - Distribution, Timing, Anatomy. Faculty of Forestry, University of Toronto, Technical Report No.9, Toronto.

Friedman, J.M., Vincent, K.R., Shafroth, P.B., 2005. Dating floodplain sediments using tree-ring response to burial. Earth Surface Processes and Landforms 30 (9), $1077-1091$

Fritts, H.C. 1976. Tree rings and Climate. Academic Press, New York, NY

Gallart, F., Puigdef ábregas, J., Del Barrio, G, 1993. Computer simulation of high mountain terracettes as interaction between vegetation growth and sediment movement. Catena 20, 529-542

Gallart, F., Solé, A., Lázaro, R., Puigdef ábregas, J., 2002. Badland systems in the Mediterranean. In: Bull, L., Kirkby, M. ( Eds.), Dryland Rivers: Hydrology and Geomorphol ogy of Semiarid Channels. Wiley, London, pp. 299-326.

Gärtner, H., 2003. Holzanatomische Analyse diagnostischer Merkmale einer Freilegungsreaktion in Jahrringen von Koniferenwurzeln zur Rekonstruktion geomorphologischer Prozesse. Dissertationes Botanicae 378, 1-118.

$\mathrm{G}$ ärtner, H., 2007. Tree roots - methodological review and new development in dating and quantifying erosive processes. Geomorphology 86, 243-251

Gärtner, H., Fritz, H., Schweingruber, F.H., Dikau, R., 2001. Determination of erosion rates by analyzing structural changes in the growth pattern of exposed roots. Dendrochronologia 19, 1-11.

Giménez, R., Marzolff, L, Campo, M.A., Seeger, M., Ries, JB., Casalí, J., Álvarez-Mozos, J. 2009. Accuracy of high-resolution photogrammetric measurements of gullies with contrasting morpholo gy. Earth Surface Pro œesses and Landforms34 (14), 1915-1926. scape connectivity in the Mancos Shale badlands and Femont River system, Utah, USA Geomorphology 102, 242-251.

Grissino-Mayer, H.D., 1993. An updated list of species used in tree-ring research. Tree Ring Research 53, 17-43.

Grissino-Mayer, H.D., 19-10-2011. Welcome to the Ultimate Tree-Ring Web Pages http://web.utkedu/ogrissino/.

Gros, R., Monrozier, L.J., Bartoli, F., Chotte, J.L., Faivre, P., 2004. Relationships between soil physico-chemical properties and microbial activity along a restoration chronosequence of alpine grasslands following ski run construction. Applied Soil Ecology 27, 7-22

Gu àrdia, R., Gallart, F., Ninota, JM., 2000. Soil seed bank and seedling dynamics in badlands of the Upper Llobregat basin (Pyrenees). Catena 40, 189-202.

Guerrero-Campo, J., 1998. Patrones de la vegetación y atributos morfo-funcionales de los terrenos erosionados de la Depresión del Ebro y del Prepirineo. Tesis Doctoral. Universidad de Barcelona.

Haubrock, S.N., Kuhnert, M., Chabrillat, S., Guntner, A, Kaufmann, H., 2009. Spatiotemporal variations of soil surface roughness from in-situ laser scanning. Catena 79 $128-139$

Hitz, O.M., Gärtner, H., Heinrich, L, Monbaron, M., 2008. Application of ash (Fraxinus excelsior L.) roots to determine erosion rates in mountain torrents. Catena 72 248-258.

Holmes, R.L., 1983. Computer-assisted quality control in tree-ring dating and measure ment. Tree Ring Research 43, 69-75.

Hupp, C.R., Carey, W.P., 1990. Dendrogeomorphic approach to estimating slope retreat, Maxey Flats, Kentucky. Geology 18, 658-661.

Jeong, J., Kannan, N., Arnold, J., Gosselink, L., Srinivasan, R., 2010. Development and integration of sub-hourly rainfall-runoff modeling capability within a watershed model. Water Resources Management 24, 4505-4527

Kasanin-Grubin, M., Bryan, R., 2004. Lithological properties and weathering response on badland hillslopes. Catena 70,68-78.

Kent, M., Owen, N.W., Dale, P., Newnham, R.M., Giles, T.M., 2001. Studies of vegetation burial: a focus for biogeography and biogeomorphology? Progress in Physical Ge ography $25,455-482$.

Koizumi, AN., Oonuma, Y., Sasali, Takahashi, K., 2007. Difference in uprooting resis tance among coniferous species planted in soils of volcanic origin. Journal of Forest Research 12, 237-242.

Ia Marche, V.C., 1963. Origin and geologic significance of buttress roots of bristlecone pines, White Mountains, California. U.S. Geological Survey Professional Paper 475-C, C149-C150.

Ia Marche, V.C., 1968. Rates of slope degradation as determined from botanical evidence, White Mountains, California. U.S. Geological Survey Professional Paper 352- I, 341-377.

Iarsson, L.A., 2003. CDendro - Cybis Dendro Dating Program. Cybis Elektronik \& Data $\mathrm{AB}$, Saltsjöbaden, Sweden

Iatrón, J., Gallart, F., 1995. Hydrological Response of Two Nested Small Mediterranean Basins Presenting Various Degradation States. Physics and Chemistry of the Earth 20 (3-4), 369-374.

Iopez-Saez,J., Corona, C., Stoffel, M., Rovéra, G., Astrade, L., Berger, F., 2011. Mapping of erosion rates in marly badlands based on anatomical changes in exposed roots and LiDAR data. Earth Surface Processes and Landforms 36, 1162-1171.

Lucía, A. Iaronne, J.B., Martín-Duque, J.F., in press. Geodynamic processes on sandy slope gullies in central Spain - field observations, methods and measurements in a singular system. Geodinamica Acta.

Malik, L, 2008. Dating of small gully formation and establishing erosion rates in old gullies under forest by means of anatomical changes in exposed tree roots (Southern Poland). Geomorpholo gy 93, 421-436.

Malik, L, Maty ja, M., 2008. Bank erosion history of a mountain stream determined by means of anatomical changes in exposed tree roots over the last 100 years (Bílá Opava River - Czech Republic). Geomorphology 98, 126-142.

Malik, L, Owczarek,P., 2009. Dendrochronological records of debris flow and avalanche in a mid-mountain forest zone (Eastem Sudetes-Central Europe). Geochronometria34 $57-66$.

Marín, C., Desir, G., 2008. Procesos de formación de coladas de barro en Bardenas Reales ( Navarra, España). In: Benavente, J., García, F.J. ( Eds.), Trabajos de geomorfología en Espa ña 2006-2008. SEG, Cádiz, pp. 93-96.

Martínez-Casasnovas, J.A., Ramos, M.C., García-Hemández, D., 2009. Effects of land-use changes in vegetation cover and sidewall erosion in a gully head of the Penedès region (northeast Spain). Earth Surface Processes and Landforms 34 (14), 1927-1937.

Mathys, N., Klotz, S., Esteves, M., Descroix, L., Lapetite, J.M., 2005. Runoff and erosion in the Black Marls of the French Alps: observations and measurements at the plot scale. Catena 63, 261-281.

McAuliffe, J.R., Scuderi, L.A, McFadden, L.D., 2006. Tree-ring record of hillslope erosion and valley floor dynamics: landscape responses to climate variation during the las $400 y r$ in the Colorado Plateau, northeastern Arizona. Global and Planetary Change 50, 184-201.

Nadal-Romero, E., Latrón, J., Martí-Bono, Regües, D, 2008a. Temporal distribution of suspended sediment transport in a humid Mediterranean badland area: the Araguás catchment, Central Pyrenees. Geomorphology 97, 601-616.

Nadal-Romero, E., Regü̈es, D., Latrón, J., 2008b. Relationships among rainfall, runoff, and suspended sediment in a small catchment with badlands. Catena 74, 127-136.

Nadal-Romero, E., Martínez-Murillo, J.F., Venmaaercke, M., Poesen, J., 2011. Scaledependency of sediment yield from badland areas in Mediterranean environments Progress in Physical Geography 35 (3), 297-332.

Nilaweera, N.S , Nutalaya, P., 1999. Role of tree roots in slope stabilisation. Bulletin of Engineering Geology and the Environment 57, 337-342. 
Osterkamp, W.R., Hupp, C. R., Stoffel, M., 2011. The interactions between vegetation and erosion: new directions for research at the interface of ecology and geomorphology. Earth Surface Processes and Landforms 37 (1), 23-36.

Park, S.W., Mitchell,J.K., Bubenzer, G.D., 1983. Rainfall characteristics and their relation to splash erosion. Transactions of ASAE 26, 795-804.

Pelfini, M., 1999. Dendrogeomorphological Study of Glacier Fluctuations in the Italian Alps during the Little Ice Age. In: Kleman, J. ( Ed.), Annals of Glaciology. International Glaciological Society, Cambridge, pp. 123-128.

Pérez-Rodríguez, R., Marques, M.J., Bienes, R., 2007. Use of dendrochronological method in Pinus halepensis to estimate the soil erosion in the South East of Madrid (Spain). The Science of the Total Environment 378, 156-160.

Poesen, J., Nachtergaele, J., Verstraeten, G., Valentin, C., 2003. Gully erosion and environmental change: importance and research needs. Catena 50, 91-113.

Regüués, D., Pardini, G., Gallart, F., 1995. Regolith behaviour and physical weathering of clayyey mudrock as dependent on seasonal weather conditions in a badland area at Vallcebre, Eastern Pyrenees. Catena 25, 199-212.

Regüiés, D., Guàrdia, R., Gallart, F., 2000. Geomorphic agents versus vegetation spreading as causes of badland occurrence in a Mediterranean subhumid mountainous area. Catena 40, 173-187.

Rey, F., Isselin-Nondedeu, F., Bedecarrats, A, 2005. Vegetation dynamics on sediment deposits upstream of bioengineering works in mountainous marly gullies in a Mediterranean climate (Southern Alps, France). Plant and Soil 278, 149-158.

Rinntech, 2008. LINTAB. Precision ring by ring. http://www.rinntech.com/Products/ Lintab.htm.

Rubiales, J.M., Bodoque, J.M., Ballesteros, J.A., Díez, A, 2008. Response of Pinus sylvestris roots to sheet-erosion exposure: an anatomical approach. Natural Hazards and Earth System Sciences 8, 223-231.

Schneuwly, D.M., Stoffel, M., Dorren, L.K.A., Berger, F., 2009. Three-dimensional analysis of the anatomical growth response of European conifers to mechanical disturbance. Tree Physiology 29, 1247-1257.

Schweingruber, F.H., 1993. Trees and Wood in Dendrochronology. Springer Series in Wood ScienceSpringer Ver lag, Heidelbeerg.
Schweingruber, F.H., 1996. Tree rings and environment. Dendroecology. Paul Haupt, Bern, Stuttgart, Wien . $609 \mathrm{pp}$

Shroder, J.F., 1980. Dendrogeomorphology: review and new techniques of tree ring dating. Progress in Physical Geography 4 (1), 161-188.

Sirvent, J., Desir, G., Gutierrez, M., Sancho, C., Benito, G., 1997. Erosion rates in badland areas recorded by collectors, erosion pins and profilometer techniques (Ebro Basin, NE-Spain). Geomorpholo gy 18, 61-75.

Soler, M., Latrón, J., Gallart, F., 2008. Relationships between suspended sediment concentrations and discharge in two small research basins in a mountainous Mediter ranean area Vallcebre, Eastern Pyrenees. Geomorphology 98, 143-152.

Stoffel, M., Bollschweiler, M., Butler, D.R., Luckman, B.H., 2010. Tree Rings and Natural Hazards: A State-of-the-art. Springer, Heildelberg, Berlin, New York.

Stoffel, M., Casteller, A, Luckman, B.H., Villalba, R, 2012. Spatiotemporal analysis of channel wall erosion in ephemeral torrents using tree roots - an example from the Patagonian Andes. Geology 40, 247-250.

Strunk, H., 1997. Dating of geomorphological processes using dendrogeomorphological methods. Catena 31, 137-151.

Thornes, JB., 1985. The ecology of erosion. Geography 70 (3), 222-236.

Tor ri, D., Calzolari, C, Rodolfi, G., 2000. Badlands in changing environments: an introduction. Catena 40 (2), 119-125.

Vandekerckhove, L., Muys, B., Poesen, J., De Weerdt, B., Coppé, N., 2001. A method for dendrochronological assessment of medium-term gully erosion rates. Catena 45 $123-161$.

Vicente, F., Sanz, M.A., Lucía, A., Martín-Duque, J.F., 2009. Evolución geomorfológica en tiempos históricos recientes de cárcavas del borde del piedemonte norte del Guadarrama. Estudio a partir de fuentes documentales. Boletín de la Real Sociedad Española de Historia Natural (Sección Geológica) 103 (1-4), 49-64.

Wang, ZY., Huang, GH., Wang, G.Q., Gao, J., 2004. Modeling of vegetation erosion dynamics in watershed systems. Journal of Environmental Engineering 130, 792

Whitford, J.A., Newham, L.T.H., Vigiak, O., Melland, AR., Roberts, AM., 2010. Rapid as sessment of gully sidewall erosion rates in data-poor catchments: a case study in Australia. Geomorphology 118 (3-4), 330-338. 